\title{
Az ion-kromatográfia retenciós elmélete és új kémiai módszerei
}

\author{
HAJÓS Péter ${ }^{\mathrm{a},}$ \\ a Pannon Egyetem, Analitikai Kémia Intézeti Tanszék, 8200 Veszprém, Egyetem u. 10.
}

\section{Bevezetés}

A klasszikus ioncsere-kromatográfia elméletében és gyakorlatában jelentős fordulatok tanúi vagyunk. A modern kémiai elválasztástudomány egyik legdinamikusabban fejlődő részterületévé vált a nagyhatékonyságú ion-kromatográfia (HPIC), amely vizes oldatokból ionos vagy ionizálható molekulák gyors, szelektív elválasztását teszi lehetővé. Erre a fejlődésre egyrészt a módszerek kémiájának széles variációja, másrészt a szilárd megosztó fázis fizikai, kémiai szerkezetében történő fejlesztések adtak módot. Az eluens oldatban ill. a szilárd pellikuláris ioncsere fázisban kialakuló kémiai mikro-egyensúlyi paraméterek, moláris frakciók, ionos töltések, komplex egyensúlyok, stabilitási viszonyok, ioncsere kapacitás stb. alapján ma már lehetőség van a szelektivitás és az elválasztások szabályozására, új kémiai módszerek tervezésére. ${ }^{1,2}$ A kutatások hasznosítása az ultra nagytisztaságú vizek vizsgálatától a többdimenziós biokémiai elválasztásokig terjednek. Ez a közlemény az MTA 2016. évi közgyülésén elhangzott előadás alapján röviden vázolja az ionkromatográfiának a kutatóhelyen kidolgozott egyensúlyi retenciós elméletét és erre építhetően példát mutat be új kémiai módszerek kifejlesztéséröl, megvilágítja a nagyhatékonyságú ioncserés analitikai elválasztások kémiai egyensúlyi hátterét.

\section{Többkomponensü szimultán ioncsere egyensúlyok}

Az ionos komponensek elválasztásában kémiai egyensúlyi megfontolások alapján lehetőség van az adott komponens várható retenciójának számítására. A két fázis $(R$ szilárd fázis, $E$ eluens oldat) között zajló megoszlási folyamatra $A$ anion esetében felírható egyensúlyi reakció

$$
y \mathrm{R}_{x}-\mathrm{E}+x \mathrm{~A}^{y-} \stackrel{K_{A / E}}{\Longleftrightarrow} x \mathrm{R}_{\mathrm{y}}-\mathrm{A}+y \mathrm{E}^{x-}
$$

ahol $K_{A / E}$ ioncsere egyensúlyi állandó, $x$ és $y$ az eluens-ion ill. a mintaion töltése. A retencióval összefüggő $D$ megoszlási hányadosra $A$ ion esetében adódik, hogy

$$
D_{\mathrm{A}^{y-}}=K_{\mathrm{A} / \mathrm{E}}^{1 / x}(Q / \mathrm{x})^{y / x}\left[\mathrm{E}^{x-}\right]^{-y / x}
$$

ahol $Q / x \quad E$ eluens-ion szilárd fázisbeli térfogatra vonatkoztatott moláris koncentrációja, amely a sztöchiometria szerint meghatározott funkciós csoportok számával, az ioncsere kapacitással, $Q$ adható meg, [ $\left.\mathrm{E}^{\mathrm{x}-}\right]$ az eluens ion oldat fázisbeli moláris koncentrációja. A $D$ megoszlási hányados értékéből a $k$ retenciós tényező számolható a fázisarány pontos ismeretében. A (2) egyenlet azonban csak egykomponensü minta és eluens-ion esetében érvényes. A valós retenciós folyamat modelljének alapja az a felismerés miszerint a minta- és eluens-ionok a mozgófázisban fellépő kémiai mellékreakciók nyomán, - az aktuális móltörteloszlásoknak megfelelően - különböző frakciókban vannak jelen, amelyek szimultán ioncsere folyamatokban együttesen határozzák meg a retenció mértékét. A komponensek ioncsere-megoszlási folyamatban való részvétele külön-külön additív tagként kezelendő, ugyanis ezek mindegyike más-más egyensúlyi jellemzővel rendelkezik, és különböző mértékben járul hozzá az ionok eredő retenciójához. A modell a lineáris analitikai kromatográfia feltételei között érvényesül. A minta és/vagy az eluens várható mellékreakciói (protolízis, ikerion- képződés, kelát- és hidroxo-komplex képződés), továbbá azok kémiai típusai és vegyértéküsége, $\mathrm{pH}$ viszonyok figyelembevételével - a modell alapján az ion-kromatográfiás módszerek rendszerbe sorolhatók. ${ }^{3,4,7}$

\subsection{Protolízis az eluens- és / vagy a minta ionban}

Többértékű mintaionok (pld. foszfát) és többkomponensű eluensek (pld. karbonát, hidrogénkarbonát, hidroxil-ionok) esetében a pH-tól függően protolízis zajlik a rendszerben, ami megváltoztatja az ionos viszonyokat. Háromértékü anion esetében a retenciót meghatározó eredő megoszlási hányadosra levezethető a (3) egyenlet:

$$
\begin{aligned}
& D_{\mathrm{A}+\mathrm{HA}+\mathrm{H}_{2} \mathrm{~A}}=K_{\mathrm{A} / \mathrm{E}}\left(\frac{\left(\mathrm{E}^{-}\right)}{\left[\mathrm{E}^{-}\right]}\right)^{3} \Phi_{\mathrm{A}}+ \\
& +K_{\mathrm{HA} / \mathrm{E}}\left(\frac{\left(\mathrm{E}^{-}\right)}{\left[\mathrm{E}^{-}\right]}\right)^{2} \Phi_{\mathrm{HA}}+K_{\mathrm{H}_{2} \mathrm{~A} / \mathrm{E}}\left(\frac{\left(\mathrm{E}^{-}\right)}{\left[\mathrm{E}^{-}\right]}\right) \Phi_{\mathrm{H}_{2} \mathrm{~A}}
\end{aligned}
$$

ahol az egyes komponensek (A,HA, $\left.\mathrm{H}_{2} \mathrm{~A}\right) \mathrm{pH}$ függő frakciókban $(\Phi)$ vannak jelen. A megoszlási folyamatot a frakciókra jellemző mintaspecifikus $K_{A / E}$ ioncsere egyensúlyi állandó szabályozza. Az eluens-ionok szilárd ioncserélő fázisbeli koncentrációja kifejezhető a $K_{E 1 / E 2}$ intereluens ioncsere egyensúlyi állandók segítségével, mint oldatbeli koncentrációjuk függvénye, ld. (4) egyenlet.

$$
Q=2\left(\mathrm{CO}_{3}^{2-}\right)+\left(\mathrm{HCO}_{3}^{-}\right)+\left(\mathrm{OH}^{-}\right)
$$

Ha ennek kifejtett formáját behelyettesítjük a (3) egyenletbe kaphatjuk a végső leíró alakot, ld. (5) egyenlet.

* Hajós Péter. Tel.: +36 308305102 ; e-mail: hajosp@almos.uni-pannon.hu 


$$
\begin{aligned}
& D_{\mathrm{A}+\mathrm{HA}+\mathrm{H}_{2} \mathrm{~A}}=\sum_{1}^{y} K_{\mathrm{A}, \mathrm{HA}, \mathrm{H}_{2} \mathrm{~A} / \mathrm{HCO}_{3} *} \\
& *\left(\frac{\sqrt{p^{2}+q}-p}{4 K_{\mathrm{CO}_{3} / \mathrm{HCO}_{3}\left[\mathrm{CO}_{3}^{2-}\right]}}\right)^{y} \Phi_{\mathrm{A}, \mathrm{HA}, \mathrm{H}_{2} \mathrm{~A}}
\end{aligned}
$$

ahol

$$
p=\left[\mathrm{HCO}_{3}^{-}\right]+K_{\mathrm{OH} / \mathrm{HCO}_{3}}\left[\mathrm{OH}^{-}\right]
$$

és

$$
q=8 * K_{\mathrm{CO}_{3}} / \mathrm{IICO}_{3} * Q
$$

Az egzakt retenciós számításokhoz szükségesek a vizsgált ionokra vonatkoztatott mintaspecifikus és az eluens komponensekre vonatkoztatott intereluens ioncsere állandók, amelyek nagyszámú kísérleti adatból iterációval nyerhetők. Széles eluenskoncentráció és pH tartományra számítva 3D retenciós felületet adhatunk meg, amely információval szolgál a mintaion (pl. foszfát) megoszlási folyamatának kémiai hátteréről, a retenció szabályozhatóságáról (lásd 1. ábra).

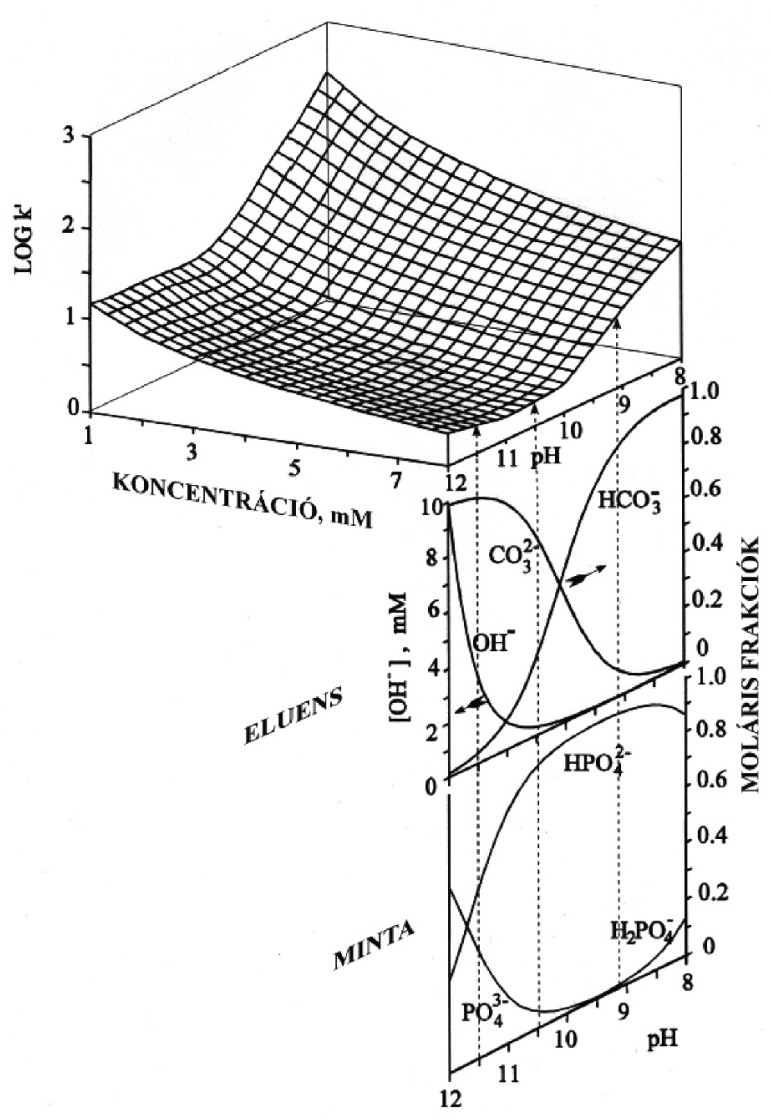

1. Ábra. Foszfát-ion retenciós felülete karbonátos elúció során. Az eluenskomponens ionok és a mintaion moláris frakciói a $\mathrm{pH}$ függvényében ${ }^{3}$
A felület minden pontja egy kromatográfiás csúcspozíciót jelöl. Két ellentétes irányú folyamat alakítja a retenció mértékét. Egyrészt, a pH növelésével nő az ionra vonatkoztatható elúciós hatás, ezért „,csökken a retenció”, mivel a kétértékü karbonát a preferált forma ebben a pH-tartományban. Másrészt, ezzel egyidejüleg nő a foszfát-ion átlagos töltése a deprotonálódás következtében, és ez a növekvő retenciónak kedvez. A két hatás eredőjeként egy minimummal rendelkező retenciós felületet kapunk. Rendhagyó retenciós tulajdonságok is magyarázhatók fentiek alapján (lásd 2. ábra). A foszfát-ion magasabb eluens pH esetében kilép a szelektivitási sorból, mivel ezen pH-tartományban a 3 értékű foszfát moláris frakciója növekszik és ezáltal a retenció nő. Ez célszerűen akkor hasznosítható, ha a minta várható foszfát-koncentrációja nagy és a kromatográfiás csúcs nagyobb bázisszélességet igényel. A fenti egyensúlyi elmélet alapján hasonló retenciós felületek, relációk, $\mathrm{pH}$ hatások adhatók meg egyéb szervetlen, szerves anionok, változó oxidációfokú klór-, bróm-oxoanionok, fém-kelát anionok esetében is. $5,6,8$

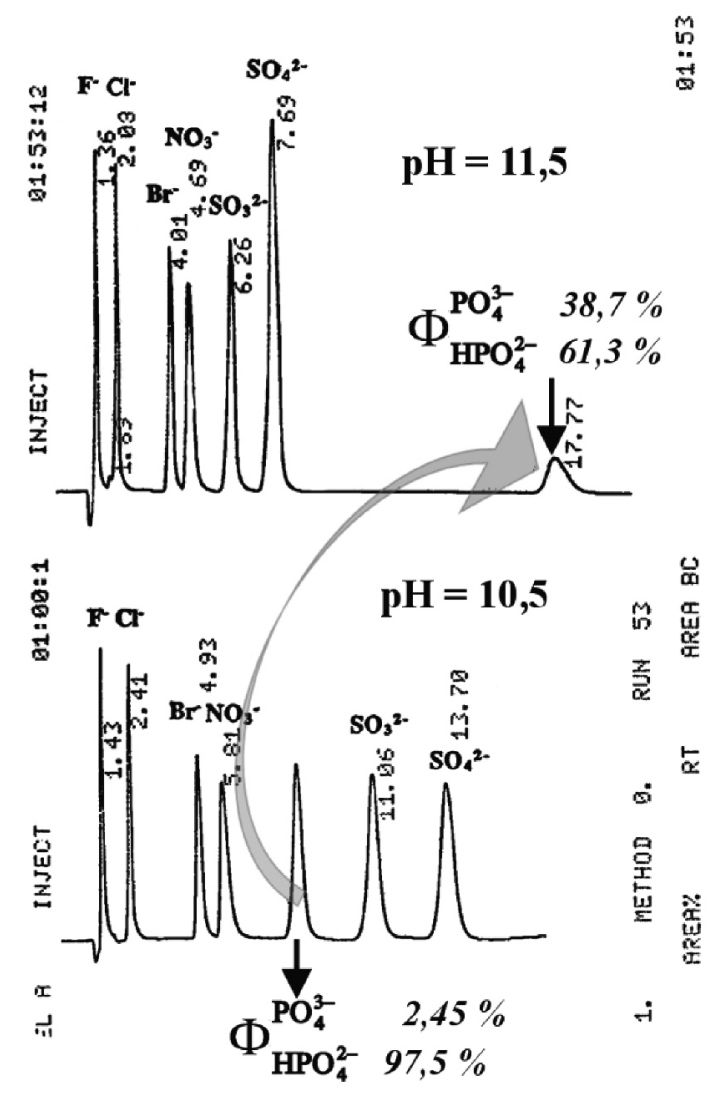

2. Ábra. Szelektivitás szabályozása az anion-kromatográfiában3

\subsection{Mátrix-ion jelenléte a mintában}

A nagyhatékonyságú ion-kromatográfia nagy szelektivitású elválasztást biztosít. Ugyanakkor léteznek olyan szélsőséges komponens kompozíciók, mátrixhatások, amelyekben a célion retencióját befolyásolja a nagy koncentrációban jelenlévő kísérő ion jelenléte. Az így előálló retenciós csúszás a célion vagy más ionok kimutathatóságát zavarja. ${ }^{2}$ Ez az úgynevezett önelúció, amely azonban egyensúlyi 
számításokkal nyomon követhető. Ha ismerjük a mátrix-ion valószínüsíthető koncentrációját és az eluensre vonatkoztatható ioncsere egyensúlyi állandóját, akkor az (5) egyenlet alapján megadható a várható retenciós felület. Ezt példázza a 3. ábra, amelyen nagy koncentrációjú szulfát mátrixban kis koncentrációjú bromát-ionok retencióját láthatjuk. Minél kisebb az eluens bázicitása ( $\mathrm{pH}$ 9-10) a növekvő koncentrációjú mátrix-ion annál nagyobb retenciós eltérést okoz. A számított ábra alapján azonban kijelölhetők azok az izo-retenciós pontok, amelyeknek megfelelő elúciós paraméterek konstans bromát retenciót biztosítanak. Így a mátrixhatás csökkenthető ill. elkerülhető.

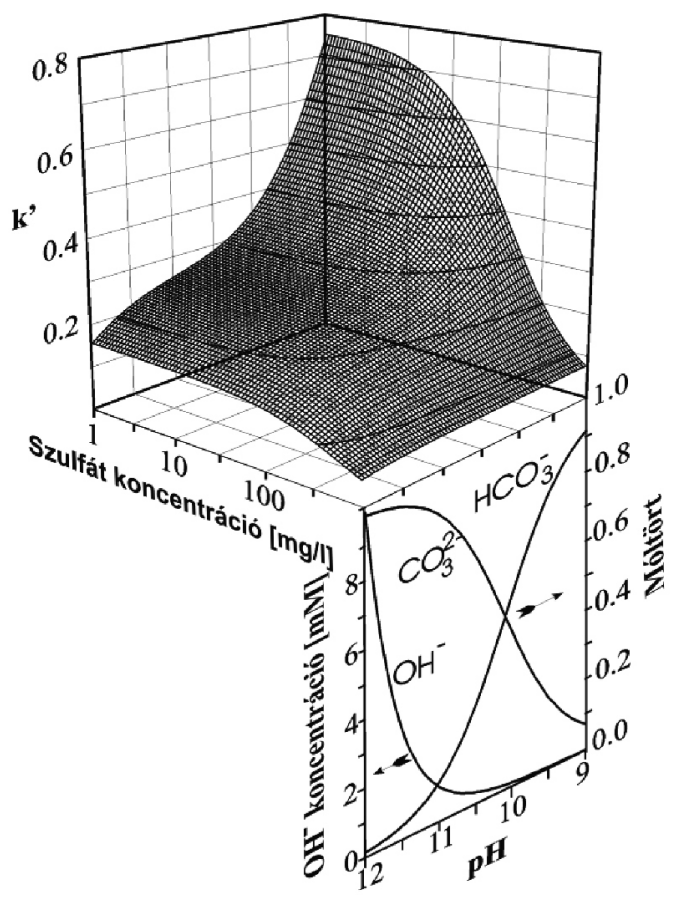

3. Ábra. Bromát-ion számított retenciója szulfát-tartalmú mátrix-ion jelenlétében ${ }^{2}$

\section{3. Új eluensrendszerek, kémiai módszerek az ion- kromatográfiában}

$\mathrm{Az}$ ion-kromatográfiában fokozott igény van olyan eluensrendszerek kidolgozására, amelyek az egyensúlyi elmélet adta lehetőségek alapján különböző minta-kompozíciók esetén is módot teremtenek szabályozható elúcióra és a szelektivitási kör jelentős bővítésére. ${ }^{9-14,16,17}$

\subsection{Fém-kelát komplex anionok elválasztási módszere és retenciós elmélete}

Komplexképző ligandumok bevezetése a minta és /vagy az eluens oldatba az ionos töltések számát és a kémiai szerkezetet szabályozó kémiai eszköz. Átmeneti-, nehézfémill. ritkaföldfém ionok (pl. $\mathrm{Cu}, \mathrm{Zn}, \mathrm{Ni}, \mathrm{Co}, \mathrm{Pb}, \mathrm{Gd}$ ) alkalmas ligandumokkal (pl. poliamino-karbonsavakkal ) bázisos $\mathrm{pH}$ közegben nagy stabilitású komplex anionokat képeznek. Pl. EDTA esetében ((8) egyenlet):

$$
\operatorname{EDTA}^{4-}+\mathrm{M}^{2+} \Longleftrightarrow(\mathrm{MEDTA})^{2-}(p H>7)
$$

Így anioncserélő oszlopon bázisos elúcióval szeparálhatók ((9) egyenlet).

$$
\begin{aligned}
2 \mathrm{R}-\mathrm{N}\left(\mathrm{CH}_{3}\right)_{3} \mathrm{OH}+(\mathrm{MEDTA})^{2-} \stackrel{K_{\mathrm{MEDTA} / \mathrm{OH}}}{\Longleftrightarrow} \\
\stackrel{K_{\text {MEDTA/OH }}}{\Longleftrightarrow} \mathrm{R}_{2}-\mathrm{N}\left(\mathrm{CH}_{3}\right)_{3} \mathrm{MEDTA}+2 \mathrm{OH}^{-}
\end{aligned}
$$

A retenciós sorrendet meghatározó tényezők: a komplex stabilitása $(\beta)$, az elúció pH-ján a komplex aktuális moláris frakciója $(\Phi)$, ligandum protonálódása $(K)$, a komplex forma ioncsere egyensúlyi állandója $\left(K_{M E D T A / O H^{-}}\right)$. Ezen adatok ill. mellékreakcióik ismeretében az (5) egyenlet alkalmazásával a várható retenció értéke számítható, az elválasztás tervezhető. Előnyös körülmény, hogy a szükséges pH-t a bázisos eluens biztosítja, továbbá ezen a $\mathrm{pH}-\mathrm{n}$ a poliamino-karbonsav ligandumok protonálódásának hatása, mint mellékreakció - minimális. Az eljárásban egyéb anionok is elválaszthatók, így a mintában eredetileg jelenlevő fémionok, és anionok szimultán ionkromatográfiás analízise is végrehajtható (4. ábra).

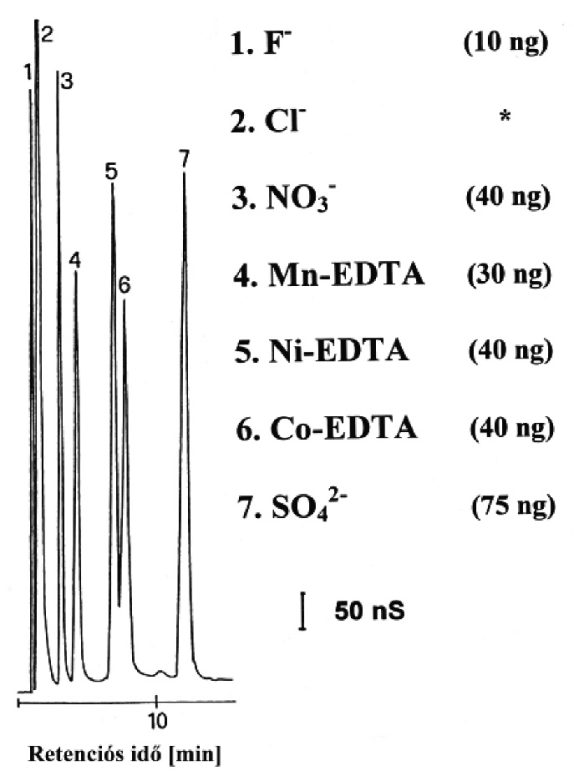

4. Ábra. Fém-kelát komplex anionok és szervetlen anionok ion-kromatográfiás elválasztása

A ritkaföldfém ionok közül kiemelendő a Gd-kelát komplex anionra kifejlesztett módszer5, tekintettel a vegyület orvosdiagnosztikai - mint in vivo MRI kontrasztanyag jelentőségére. Az 5. ábrán a $\mathrm{Gd}$ - dietilén-triaminpentaacetát komplex anion elválasztását látjuk szerves mátrix ionok jelenlétében.

\subsection{Makrociklikus ioncsere módszere és retenciós elmélete haloacetátok elválasztására}

Ha a szilárd polimer fázisba funkciós csoportként makrociklikus molekulát kötünk (pl. n-decil-2.2.2 kriptát), akkor újabb szelektivitást növelő kémiai paramétereket vezetünk be. Alkáli hidroxid eluens alkalmazása esetén a szilárd fázisban kialakuló alkáli kriptát anioncserélőként 


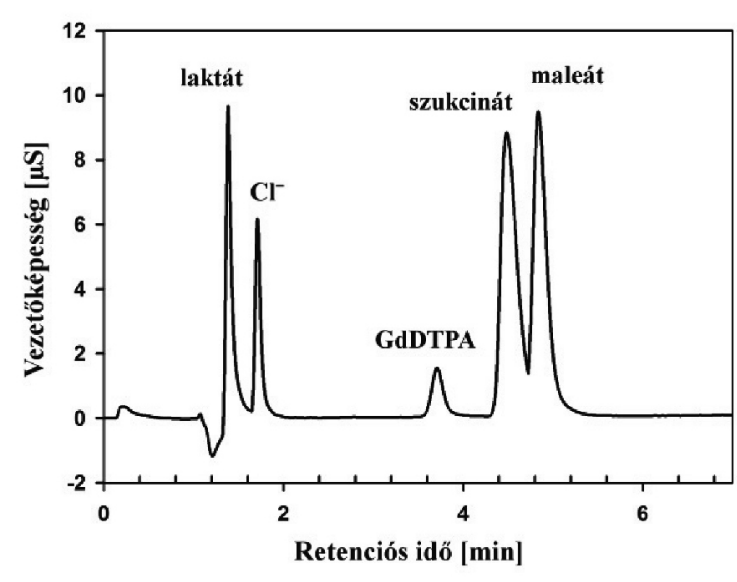

5. Ábra. (Gd-DTPA $)^{2-}$ komplex anion és szerves anionok ion-kromatográfiás elválasztása ${ }^{5}$

funkcionál. Az alkáli ion kiválasztása, a fémion rádiusza, a makrociklus kavitása, polarizálhatósága, az alkáli-kriptát komplex stabilitása, a komponensek ioncsere egyensúlyi jellemzői retenciót befolyásoló tényezők, amelyek értéke becsülhető és az elválasztás az (5) egyenlet alapján tervezhető.15 Az alkáli hidroxid eluens koncentrációjával a makrociklikus komplex móltört eloszlását szabályozhatjuk, ezáltal a Q ioncsere kapacitást befolyásoljuk. Ez a retenció mértékére hat. Az alkáli minőségével ( $\mathrm{Li}, \mathrm{Na}$, vagy $\mathrm{K}$ ) a szelektivitást tudjuk befolyásolni, mivel így gyenge, közepes vagy erős bázicitású anioncserélő lesz jelen. Ezek kombinációja előnyös gradiens elválasztásokat tesz lehetővé (6. ábra).

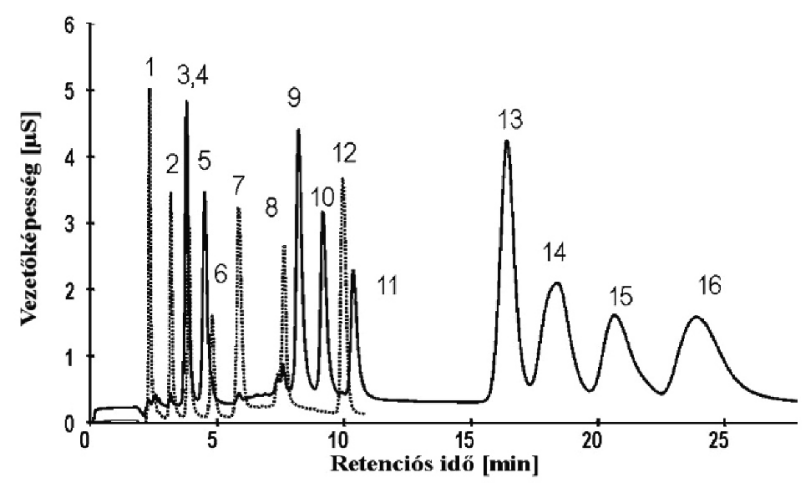

6. Ábra Mono-/ di-/ tri- klór-bróm acetátok elválasztása makrociklikus anioncserélön gradiens elúcióval ( $\mathrm{Na} / \mathrm{K}$-n-decil-2.2.2 kriptát $)^{15}$

1 - fluorid, 2 - klorid, 3 - monoklór-acetát, 4 - nitrit,

5 - monobróm-acetát, 6 - bromid, 7 - nitrát, 8 - szulfát,

9 - diklór-acetát, 10 - brómklór-acetát, 11 - dibróm-acetát, 12 - foszfát,

13 - triklór-acetát, 14 - monobróm-diklór-acetát, 15 -

monoklór-dibróm-acetát, 16 - tribróm-acetát

\section{Köszönetnyilvánítás}

A jelen közlemény alapját képező munkákat támogatták az OTKA K81843 és a GINOP-2.3.2-15-2016-00016 nyilvántartási számú projektek.

\section{Hivatkozások}

1. Hajós P.; Horváth O.; Révész G. Adv. Chromatography Marcel Dekker Inc., New York, 1998, 39, 311

2. Hajós P.; Horváth K. J. Chrom. A, 2008, 1199, 101-106. https://doi.org/10.1016/j.chroma.2008.05.011

3. Hajós P.; Horváth O.; Denke V. Anal. Chem. 1995, 67, 434. https://doi.org/10.1021/ac00098a032

4. Tófalvi R.; Horváth K.; Hajós P. J. Chrom. A, 2013,1272, 26 https://doi.org/10.1016/j.chroma.2012.11.054

5. Hajós P.; Lukács D.; Farsang E.; Horváth K. J. Chrom. Sci. 2016, 1-9. https://doi.org/10.1093/chromsci/bmw133

6. Fóti Gy.; Hajós P.; Pellaton G.; Kováts sz. E. Anal. Chem. 1996, 68, 2580-2589. https://doi.org/10.1021/ac9600159

7. Madden J.; Haddad P.R.; Hajós P. TrAC, Trends in Analytical Chemistry, 1996, 15, 531. https://doi.org/10.1016/S0165-9936(96)00067-2

8. Hajós P.; Horváth O.; Révész G.; Peear J.; Sarzanini C. Progress in Ion Exchange: Advances and Applications (Editors: A. Dyer, M.J. Hudson, P.A. Williams) The Royal Society of Chemistry, Cambridge, ISBN: 0-8247-0159-3, pp.144-152, 1997

https://doi.org/10.1533/9781845698652.2.144

9. Hajós P.; Révész G.; Horváth O.; Peear J.; Sarzanini C. J. Chrom.Sci. 1996, 34, 291-299.

https://doi.org/10.1093/chromsci/34.6.291

10. Hajós P.; Révész G. J. Chrom.A, 1997, 771, 23-33. https://doi.org/10.1016/S0021-9673(97)00077-0

11. Hajós P. J. Chrom. A, 1997, 789, 141-148. http://dx.doi.org/10.1016/S0021-9673(97)00524-4

12. Hajós P.; Nagy L. J. Chrom. B, 1998, 717, 27-38. https://doi.org/10.1016/S0378-4347(98)00247-3

13. Hajós P. J. Chrom. A, 2002, 955, 1-8. https://doi.org/10.1016/S0021-9673(02)00225-X

14. Horváth K.; Hajós P. J. Chrom. A, 2006, 1104, 75-81 https://doi.org/10.1016/j.chroma.2005.11.064

15. Bruzzoniti M.C.; De Carlo R.M.; Horváth K.; Hajós P.; Perrachon D.; Prelle A.; Tófalvi R.; Sarzanini C. J. Chrom. A, 2008, 1187(1-2), 188-96. https://doi.org/10.1016/j.chroma.2008.02.028

16. Conca R.; Bruzzoniti M.C.; Sarzanini C.; Hajós P. Anal. Chim. Acta, 2001, 439, 107-114. https://doi.org/10.1016/S0003-2670(01)01022-4

17. Hajós P.; Horváth K.; Conca R.; Sarzanini C. Chromatographia, 2002, 56, 103-107. https://doi.org/10.1007/BF02494121 


\section{Retention theory and method developments in high performance ion chromatography}

The use of high-performance ion exchange chromatography for the separation of inorganic and organic cations, anions, oxoanions, metal chelate complex anions and ionizable molecules has become an attractive and viable method during the past decades. In this article we have presented a retention theory based on chemical equilibria associated with practical considerations for ion chromatography. The major factor in the control of selectivity for this system is the imposition of chemical equilibria on the ion exchange distribution. The variability of the eluent and solid phase composition with protonation and chelating, macrocyclic ligands can be used to exploit a wide range of secondary chemical equilibria and thereby obtain a very broad scope for ion-chromatography.

The versatility of ion chromatography has been significantly developed by the application of multiple species eluent as carbonate buffer eluent. However, ion exchange equilibria are strongly dependent on interactions between the species in the mobile and the stationary phases. The strength of an eluent can be manipulated simply by changing the $\mathrm{pH}$. The system that contains several ionic species in the eluent and different forms of analytes in the sample is rather complicated. In order to have a reliable retention model, all the forms of species in the system must be considered. The equilibrium based multiple eluent / analyte species model was developed and derived as a mean of considering all competing ions by taking into account their differing selectivities. Ion - specific and intereluent selectivity constants were determined from the wide range of experimental retention data by iterative calculations using the derived equations. The results of retention data for phosphate ions eluted with carbonate buffer in quantitative three-dimensional retention surfaces $(\log \mathrm{k}$, eluent concentration, $\mathrm{pH}$ ) together with species distribution graphs are also presented.

A common problem of the most HPIC methods is that in the real samples there are a great amount of matrix components together with the trace level analytes. The retention behavior of low concentration bromate anions was studied systematically as a function of changing high matrix, sulphate concentration. Stochiometric retention model was developed for interpretation and prediction of matrix effects. The method describes precisely the retention shift of trace anions in the high level of ionic matrix.

An simple ion chromatographic method was developed for the separation of transition-, heavy- and rare earth metal chelates $(\mathrm{Cu}, \mathrm{Zn}, \mathrm{Ni}, \mathrm{Co}, \mathrm{Pb}, \mathrm{Gd})$ and free anionic complexing ligands (EDTA, DCTA, DTPA) using alkaline carbonate eluents and conductivity detection. When basic solutions contains an excess of a strong complexing anion of high charge such as polyamino-carboxylic acids , most metal ions will occur as anionic complexes. The metal-EDTA complexes are anions and can be separated by anion exchange. Hence, this method provides simultaneous metal and anion analysis. The system was utilized to separate metal-chelate complex anions, chelating ligands and common anions. The complex equilibria of separations were studied in order to understand major factors in the control of selectivity and retention order of complex anions The method is also useful for species identification and simultaneous analysis of Gd-complexes and aliphatic organic / inorganic anions.

In our work we also report retention behaviors of chlorinated-brominated haloacetic acids (HAAs: MCA monochloroacetic acid, MBA - monobromoacetic acid, DCA - dichloroacetic acid BCA - bromochloroacetic acid, DBA - dibromoacetic acid, TCA - trichloroacetic acid, MBDCA - monobromo-dichloroacetic acid, MCDBA monochloro-dibromoacetic acid, TBA - tribromoacetic acid) on a macrocycle based anion exchanger containing covalently bound n-decyl-2.2.2 cryptand (D222) using gradient hydroxide elution and suppressed conductivity detection. Since most macrocycles are neutral molecules, when the cation are complexed into the macrocycle a positively charged functional group is generated which then provides the site for anion exchange with high selectivity. 